\title{
WHITE CELL AND PLATELET COMPONENT SUPPORT IN HUMAN BONE MARROW TRANSPLANTATION
}

\author{
LUCILLE WOOD, R.N., R.M. \\ Senior sister in charge, Cell Support Section and clinics
}

\author{
PETER JACOBS, M.B., Ph.D. \\ Professor and Head from The University of Cape Town Leukaemia Centre \\ and the Department of Haematology Groote Schuur Hospital.
}

\section{OPSOMMING}

\begin{abstract}
Daar was twee aanduidings vir die infusie van geellaag aan pasiënte wat 'n beenmurgoorplanting ondergaan het. Eerstens is daar in die vyf dae na die allogeniese beenmurgoorplanting bykomende bloedvormende stamselle vanaf die skenker gekry om dié wat tydens die oorspronklike beenmurgoorplanting toegedien is te versterk. Die volwasse granulosiete en trombosiete voorkom daarby ook infeksie en bloeding. Tweedens is geellaag terapeuties vanaf die tweede week toegedien waar pasiënte pansitopenie of koors ontwikkel het wat nie op toepaslike antibiotiese terapie reageer het nie óf waar pasiënte opvallende trombositopeniese bloeding gehad het. Dié ondersteuning is volgehou totdat beenmurgregenerasie plaasgevind het.

Sel-hulpprogramme is nou 'n noodsaaklike deel van beenmurgoorplantingsprogramme en die doeltreffendheid va!ı die programme berus op die daadwerklike deelname van 'n stabiele en hoogs ervare verpleegspan.
\end{abstract}

\section{INTRODUCTION}

Bone marrow transplantation is the preferred form of treatment for patients with severe acute aplastic anaemia ${ }^{1}$ and immunodeficiency disease $^{2}$. The procedure has also been used in the treatment of patients with refractory or relapsed acute leukaemia and may result in further disease-free periods in excess of two years in approximately $15 \%$ of such individuals ${ }^{3}$. On the basis of the latter experience bone marrow transplantation is now being evaluated in patients with acute leukaemia who have achieved their first complete remission. Preliminary data both for lymphoblastic ${ }^{4}$ and myeloblastic ${ }^{5}$ variants suggest that such an approach may hold advantages over cytotoxic maintenance programmes. Other possible indications for this procedure, while still controversial, include lethal genetically transmitted diseases such as thalassaemia major, constitutional or familial bone marrow failure, and chronic granulocytic leukaemia. Understandably, the morbidity and mor- tality that currently attend marrow transplantation are factors limiting its wider clinical use.

Two immunologic barriers influence the outcome of any transplantation procedure. The first of these is the satisfactory acceptance of the graft; failure to engraft is designated rejection. Best results are obtained by matching donor and recipient at the major histocompatibility complex. Despite HLA compatibility and mixed lymphocyte culture non-reactivity, problems may arise because of isoimmunisation of the recipient by prior administration of blood products. It is for this reason that transfusions should be minimised, ideally by early referral of patients. To encourage engraftment, the immunologic competence of the recipient is suppressed by drugs, such as cyclophosphamide, with or without whole-body radiotherapy. This preparative treatment is associated with destruction of residual haematopoietic tissue and thus contributes to the pancytopenia that characterises the post-transplantation period, when severe infection and thrombocytopenic bleeding are common problems.

Secondly, morbidity and mortality may result from graft-versushost disease or reverse rejection. Here, an inflammatory reaction is directed predominantly against the cells of the gastrointestinal tract. the liver, and the skin, but its pathogenesis is controversial ${ }^{6}$. Because it is rare in identical twins or syngeneic transplants, importance is attached to optimal matching of donor and recipient. Nevertheless, the clinical syndrome, which may be either acute or chronic, occurs in up to $70 \%$ of apparently perfectly matched transplantation pairs. A prominent component of this syndrome is infection, where allogeneic granulocyte support may be life-saving.

The steady improvement in results of bone marrow transplantation must take into account the importance of specialised nursing and, particularly, the role of an efficient cell support section. The latter is needed to provide, on a moment- 
to-moment basis, adequate numbers of functionally viable white cells and platelets. It is this facet of the programme that is illustrated by experience derived from five recently transplanted patients.

\section{CASE REPORTS}

\section{Case No 1}

POOR PROGNOSIS ACUTE LYMPHOBLASTIC LEUKAEMIA

A 10-year-old boy presented with a 12-day history of fever and headache, undue fatigue, and petechiae in the 24 hours before admission. Physical findings were limited to firm enlarged lymph nodes in the neck, axilla, and groin, and $4 \mathrm{~cm}$ hepatosplenomegaly. Initial haematology showed a haemoglobin of 9.8 $\mathrm{g} / \mathrm{dl}$; total white cell count of $114 \mathrm{x}$ $10^{9} / 1$, all lymphoblasts; and a platelet count of $60 \times 10^{9} / 1$. The biochemical profile was normal. Bone marrow examination confirmed the diagnosis of acute lymphoblastic leukaemia (FAB type LI) ${ }^{7}$. Lumbar puncture revealed the presence of numerous lymphoblasts in the cerebrospinal fluid. Radiology of the dorsal spine showed mild osteoporosis and vertebral collapse without positive evidence of leukaemic infiltration.

Complete remission was achieved successfully with a combination of vincristine, prednisone, $\ell$-asparaginase and adriamycin. The central nervous system was cleared of leukaemic blasts with twice weekly alternating intrathecal cytosine arabinoside $\left(30 \mathrm{mg} / \mathrm{m}^{2}\right)$ and methotrexate $\left(12 \mathrm{mg} / \mathrm{m}^{2}\right)$. Two courses of consolidation chemotherapy were given using the four induction drugs. Standard craniospinal therapy was given without complication $^{8}$.

In view of the bad prognosis predicted by the high circulating blast count and the presence of central nervous system disease, the patient and his family were offered bone marrow transplantation in this first complete remission. An HLA identical and MLC non-reactive 12year-old brother acted as donor after informed consent had been obtained.

Following placement of a central venous catheter ${ }^{9}$ the patient was prepared with cyclophosphamide, $60 \mathrm{mg} / \mathrm{kg}$, administered by intravenous infusion on two consecutive days with attention to fluid balance and electrolyte status. Following a 24-hour rest period total body irradiation was given to a mid-plane dose of 1000 rads; the skull was shielded at 500 rads to compensate for previous administration of 3200 rads cranial irradiation.

Under general anaesthetic $440 \mathrm{ml}$ of marrow was collected from the donor by multiple percutaneous punctures from the sternum and both iliac crests. $2.3 \times 10^{8}$ nucleated cell $/ \mathrm{kg}$ were infused into the recipient. The adequacy of the donor marrow was confirmed by in vitro bone marrow culture. The donor was discharged from hospital 24 hours after marrow donation.

In the post-transplantation period the patient received daily parenteral intravenous alimentation. For five days following infusion of the marrow the donor buffy layer was infused providing both white cells (mean of $2.2 \times 10^{10}$; range $\left.0.7-4.0 \times 10^{10}\right)$, and platelets (mean of $0.4 \times 10^{11}$; range $0.2-$ $\left.0.8 \times 10^{11}\right)$.

Because the patient remained pyrexial despite an intravenous antibiotic regimen of cephalosporin, aminoglycoside and metranidazole, allogeneic white cell support was continued until day 14 when the temperature returned to normal.

Successful engraftment was confirmed by a rising peripheral platelet and granulocyte count on day 12. Trephine biopsy was hypocellular but all lines were represented.

\section{Comments}

The immediate post-transplantation course in this patient was characterised by mild to moderate graftversus-host disease with persisting skin rash and transient diarrhoea requiring intravenous hyperalimentation and corticosteroids ${ }^{10}$. There are residual Cushingoid striae but no measurable endocrine abnormalities. The osteoporosis, perhaps due to leukaemic infiltration, has resolved with calcium and vitamin D supplementation.

A transient period of jaundice was unexplained and may have been the result of viral infection from transfusion therapy, a reflection of graft-versus-host disease, or incidental infectious hepatitis. One year from transplantation the patient again had elevation in liver enzymes and mild conjugated hyperbilirubinaemia. There were no demonstrable antibodies against hepatitis A or B, and the possibility of intermittent biliary tract obstruction was considered but $n \in v^{-r}$ proven.

The patient has remained immunocompromised with hyperglobulinaemia and has received parenteral gammaglobulin. In addition, he has had an episode of staphylococcal septicaemia requiring six weeks of intravenous antibiotics. Recovery was uneventful. One year after being transplanted, he developed an acute abdomen requiring emergency laparotomy. Pigment gallstones obstructing the common bile duct were found. The patient handled wound healing and his surgery without difficulties.

At the present time, one and a half years after successful bone marrow transplantation and despite a variety of complications, he is disease-free and has mild (Grade I - II) but steadily resolving graftversus-host disease.

\section{Case No 2}

\section{POOR PROGNOSIS ACUTE UN- DIFFERENTIATED LEUKAEMIA}

A 22-year-old student presented with a one week history of anaemia and bleeding from his gum margins. Physical examination was negative apart from $1 \mathrm{~cm}$ hepatosplenomegaly. Initial haematology showed a haemoglobin of $12.5 \mathrm{~g} / \mathrm{d} 1$; total white cell count of $35 \times 10^{9} / 1$ with $11 \%$ neutrophils, $5 \%$ eosinophils, $1 \%$ basophils, $38 \%$ lymphocytes (many of which were atypical), $6 \%$ monocytes, $3 \%$ promyelocytes, $5 \%$ myelocytes, $31 \%$ metamyelocytes; platelet count was $146 \mathrm{x}$ $10^{9} / 1$. The biochemical profile was normal. Bone marrow examination showed marked hypercellularity and many ringed sideroblasts. The marrow was extensively involved with undifferentiated acute leukaemia.

Initial attempts to induce remission in the patient with a combination of an anthracycline antibiotic, 
cytosine arabinoside and the epipodophyllotoxin VP $16-213^{11}$ were unsuccessful. Remission was subsequently achieved with the combination of vincristine, prednisone, $\ell$ asparaginase and adriamycin. Following two courses of consolidation the patient was offered bone marrow transplantation in view of the poor prognosis associated with acute undifferentiated leukaemia.

Conditioning was with the standard regimen of cyclophosphamide and total body irradiation ${ }^{12}$. He recieved $4 \times 10^{8}$ nucleated cells $/ \mathrm{kg}$ from an HLA identical MLC nonreactive brother. The adequacy of the donor marrow was confirmed by in vitro bone marrow culture. Post-transplantation stem cell boosting was provided with administration of buffy layer for five days. Mean white cell yield $3.4 \times 10^{10}$ (range $1.7-3.8 \times 10^{10}$ ). Mean platelet yield $.6 \times 10^{11}$ (range $.5-$ $1.2 \times 10^{11}$ ). No further cell support was needed.

\section{Comments}

Mild to moderate graft-versus-host disease developed which responded dramatically to $1.5 \mathrm{mg} / \mathrm{kg}$ parenteral prednisone $/ 24$ hours and did not reappear when the corticosteroid was withdrawn. The patient developed an acute abdomen with radiologic and ultrasonographic evidence of acute biliary tract obstruction. He rapidly developed fulminating septicaemia and died before surgery could be undertaken.

At post mortem biliary obstruction had occurred as a result of a mucosal cast having impacted and totally obstructed the common bile duct. No residual evidence of leukaemia was demonstrated and bone marrow engraftment was confirmed.

\section{Case No 3}

\section{SEVERE ACUTE APLASTIC ANAEMIA}

A 35-year-old woman was referred in extremis after having been ill for six weeks. There had been bruising and minor trauma with severe headache and vaginal bleeding for four weeks. Examination showed ecchymoses around both eyes and extensive purpura was present. There was marked neck stiffness and the patient was stuperose although moving all her limbs. Pupils were equal and responsive. No other focal or neurologic signs were present. Lumbar puncture showed bloodstained cerebrospinal fluid.

Initial haematology showed a haemoglobin of $2.7 \mathrm{~g} / \mathrm{d} 1$; white cell count of less than $1 \times 10^{9} / 1$ and platelets less than $10 \times 10^{9} / 1$. Only lymphocytes were circulating in the peripheral blood. The biochemical profile was normal. Bone marrow aspiration and the trephine biopsy showed aplasia.

The patient was initially managed conservatively from the standpoint of her sub-arachnoid haemorrhage with irradiated allogeneic platelet transfusions. She responded well to this management and once fully conscious and able to make decisions accepted bone marrow transplantation. A central venous line was placed and conditioning undertaken with a standard regimen of cyclophosphamide. Total body irradiation was not used.

The patient was uneventfully transplanted from her HLA identical and MLC non-reactive sister, receiving $3.8 \times 10^{8}$ nucleated cells $/ \mathrm{kg}$ and the graft viability was established by in vitro marrow culture.

The patient received five days post-transplantation buffy layer to supplement haematopoietic stem cells; mean white cell yield $1.2 \mathrm{x}$ $10^{10}$ (range $0.5-2.3 \times 10^{10}$ ) and platelets with a mean of $1.0 \times 10^{11}$ (range $0.5-1.9 \times 10^{11}$ ). Engraftment was demonstrated by rising peripheral count confirmed by trephine biopsy on the 12th post-transplant day.

On the 11th post-transplant day, after buffy layer had been discontinued, the patient was again pyrexial and had an episode of fresh rectal bleeding. Allogeneic white cells and platelets were recommended and the patient was unexpectedly found dead in bed on the 17 th post-transplantation day.

\section{Comments}

The pyrexial episode was investigated with blood cultures which failed to grow an organism. Nevertheless, the standard antibiotic regimen of cephalosporin, aminoglycoside and metranidazole were com- menced and because the fever persisted allogeneic white cells were infused.

The cause for the rectal bleeding was never established but the patient remained thrombocytopenic at this stage and there was a prompt response to platelet infusion.

Post mortem examination failed to reveal the cause of death. No cerebral bleeding was demonstrated. Marrow engraftment was confirmed.

\section{Case No 4}

\section{FANCONI ANAEMIA}

A diagnosis of Fanconi anaemia was made at the age of 12 when the patient was seen with easy bruising and thrombocytopenia. During the ensuing years these symptoms were moderately controlled on low doses of corticosteroids. In the year preceding his referral he had failed to respond to anabolic androgens and was developing an increasing blood transfusion requirement. On admission he was pale and listless. Scattered purpura and ecchymoses were present. He was markedly Cushingoid.

Initial haemoglobin was $4.3 \mathrm{~g} / \mathrm{dl}$; total white cell count $4.8 \times 10^{9} / 1$ with $22 \%$ neutrophils; platelet count was $3 \times 10^{9} / 1$. Bone marrow showed erythroid hypoplasia with marked megaloblastic change normal granulopoiesis, and scanty megakaryocytes. In view of the rapid deterioration and despite the presence of a strong multispecific antibody, the patient was conditioned with a standard regimen of cyclophosphamide and transplanted from an HLA identical and MLC non-reactive sister.

Particularly in view of previous sensitisation, importance was attached to the buffy layer support which yielded a mean white cell count of $1.3 \times 10^{10}$ (range $0.5-3.6$ $\left.x 10^{10}\right)$ and a mean platelet count of $0.5 \times 10^{11}\left(0.5-1.4 \times 10^{11}\right)$.

In the two weeks following transplantation, most prominently between days 10 and 14 , the patient developed severe mucositis, diarrhoea and skin desquamation. His hands became swollen and deep bullous lesions developed over the knuckles. These cutaneous findings 
were associated with the isolated biochemical abnormality of a rising total and conjugated bilirubin.

This clinical syndrome was interpreted as being due to acute graftversus-host disease and the patient treated with high doses of corticosteroids.

Despite the obvious progression of this immunologic syndrome, engraftment was demonstrated on the 12th post-transplant day by rising granulocyte and platelet count. Confirmation was obtained by bone marrow aspiration and trephine biopsy.

There was rapid progression of the graft-versus-host disease and by the 21st post-transplant day it was progressing to scleroderma. On the same day there was a dramatic temperature rise and the patient died from fulminating septicaemia superimposed upon his graftversus-host disease.

Autopsy confirmed the presence of engraftment and extensive graftversus-host disease.

\section{Comment}

Bone marrow transplantation in patients with constitutional anaemia, as exemplified by the Fanconi syndrome, remains controversial although successful cases have been reported. The uncertainty rests upon an inability to ensure that the donor is not also affected by the same chromosomal abnormality as the patient. In the present case appropriate studies excluded this possibility although more subtle lesions may have existed and escaped attention by available techniques.

This patient exemplifies the situation where post-transplantation stem cell boosting with buffy layer has been most encouraging. In individuals sensitised from previous exposure to blood or components there is limited evidence that immune rejection may be compensated for by buffy layer infusion. Clearly, at least in the short term, the transplantation was successful in re-establishing haematopoietic function.

The acute graft-versus-host disease is believed to represent direct transmission of sensitised lymphocytes from donor to recipient in the marrow graft. The onset and the clinical course are typical of the acute variant of graft-versushost disease and, despite the administration of high-dose corticosteroids, the course followed by this patient is in keeping with that described by other more experienced investigators.

\section{Case No 5}

\section{SEVERE ACUTE APLASTIC ANAEMIA}

A 25-year-old female presented with a one-month history of lower abdominal pain which was diagnosed as salpingitis and treated with an unknown antibiotic by her private physician. Shortly thereafter she experienced epistaxis and menorrhagia, followed by increasing dyspnoea, palpitations, and a sharp decline in effort tolerance. Apart from the antibiotics there was no history of drug ingestion. Physical examination was normal except for bilateral fundal haemorrhages.

Initial laboratory findings included a haemoglobin of $6.0 \mathrm{~g} / \mathrm{dl}$; white cell count $1.5 \times 10^{9} / 1$, with $88 \%$ lymphocytes; and platelet count of $13 \times 10^{9} / 1$. The biochemical profile and chest $\mathrm{X}$-ray were normal. Bone marrow aspirate and trephine biopsy showed aplasia. Following conditioning with cyclophosphamide, the patient was transplanted from an HLA identical and MLC non-reactive brother, followed by five days post-transplantation buffy layer administration. The mean white cell yield was $2.5 \times 10^{10}$ (range $0.9-3.7 \times 10^{10}$ ) and mean platelets were $1.0 \times 10^{11}$ (range 0.3 $-1.8 \times 10^{11}$ ).

In the second week low grade fever continued despite appropriate antibiotics and in view of the pelvic inflammatory disease with which the patient presented, allogeneic granulocyte support was continued.

By day 13 the temperature had settled and engraftment confirmed by bone marrow aspirate and trephine biopsy. All support was discontinued from the end of the second post-transplantation week.

\section{Comment}

This patient developed rapidly increasing weakness ascribed to the administration of epsilon aminoca- proic acid which she received in large amounts for her menorrhagia $^{13}$. Her course was further complicated by the development of septicaemia, and death resulted from sub-arachnoid haemorrhage.

\section{CELL SUPPORT}

The machine used for the collection of buffy layer is the NCI-IBM 2990 or, more recently, the 2997 , both of which operate on the principle of differential centrifugation. The essential difference between the two machines is that the newer NCIIBM 2997 has a disposable bowl so that risk to individuals on the machine from infection is no longer present. The blood leaves an arm vein of the donor and enters a slowly spinning centrifuge bowl where the white cells and platelets are segregated from the red cells and may be selectively removed. with all other components being returned to the donor.

In the NCI-IBM 2990 the polycarbonate bowl is primed with 100() $\mathrm{ml}$ of $0.9 \%$ saline containing 5000 units of heparin. Following cannulation of the patient a further 5000 units of heparin are administered as an intravenous bolus. A centrifuge speed of approximately $600 \mathrm{rpm}$. is used and flow rates vary between 30 and $50 \mathrm{ml} /$ minute. Under these circumstances the leucocyte and buffy layer is evident as a yellow band situated between the red cells and the plasma, and is visible through the transparent perspex deck of the centrifuge bowl. Extraction of white cells and platelets takes place at a rate between 3 and $6 \mathrm{ml} / \mathrm{min}$ ute, and between 150 and $300 \mathrm{ml}$ is usually collected from each donor.

Donations require informed consent and predonation full blood counts are routinely obtained on each occasion. Donor temperature. blood pressure and pulse are monitored throughout the course of the procedure. The donor, in addition to having given marrow, is routinely used in the five days immediately following transplantation with the theoretical intention of enhancing the number of haematopoietic stem cells administered to the recipient.

In those patients where fever and granulocytopenia, often associated with thrombocytopenia, are en- 
countered, a further 10 to 14 days donation of buffy layer is possible from the same donor without either undue difficulty or stress. If the original volunteer is unable to continue donations while the recipient is still dependent upon allogeneic cells, $\mathrm{ABO}$ compatible relatives and unrelated donors are used. Under these circumstances the granulocytes are irradiated to 1500 rads to prevent proliferation of lymphoid cells which might produce or enhance graft-versus-host disease.

A number of manipulations can be used to increase the yield of buffy layer collections, including corticosteroid administration to the donor and addition of hydroxyethyl starch to the venous line supplying blood to the bowl. The latter substance may cause headache due to volume expansion, decrease in haemoglobin and platelets due to haemodilution in the donor, and pruritis.

In contrast to differential centrifugation the alternative technique of continuous-flow filtration may be used for granulocyte collection. However, only centfiguation is suitable for buffy layer collection since stem cells, lymphocytes, platelets, and granulocytes are collected by this technique.

Where filtration is used, high granulocyte yields may be obtained but there is recent evidence that the cells obtained are functionally and ultrastructurally inferior to those recovered following centrifugation.

In order to obtain cells by filtration heparinised blood is passed over nylon filters at flow rates between 40 and $100 \mathrm{ml} /$ hour. Granulocytes adhere to the filter and recovered by elution with a citratecontaining solution. Other cellular components do not remain in the filter. Because a volume in excess of 10 litres needs to pass over the filter donations usually require two hours. A recent modification has been the use of in-line elution but this remains largely developmental. It has, however, been suggested. but not yet proven, that both cell yield and function are significantly improved by this approach.

During elution granulocytes can be dislodged from the filter by percussion of the casings and cells then concentrated by centrifugation at
$1600 \mathrm{x} \mathrm{g}$ for 20 minutes. The final volume infused varies between 100 and $300 \mathrm{ml}$, and should take place within one hour of collection.

Complications occur with both techniques. With centrifugation there may be a drop in haemoglobin which requires correction by administration of fresh irradiated packed red cell. Thrombocytopenia which is transient occurs rarely. In a number of patients venous access may be difficult, requiring the use of arterio-venous shunts. Clotting may occur in the extracorporeal circulation due to insufficient use of anticoagulant but this should not be encountered when experienced staff operate the machine. Similarly, anxiety occurs in some donors but can be overcome by the presence of experienced and competent nursing and medical staff.

The complications arising from haemofiltration also include difficulties with venous access and clotting. However, here an abdominal pain syndrome is recognised which is believed to reflect complement activation.

\section{BONE MARROW TRANS- PLANTATION PROCEDURE}

Donors commence oral iron and folate supplementation two weeks before transplantation. One unit of whole blood is collected in the week before transplantation. The buffy layer is separated and administered to the recipient 24 hours before commencement of the cyclophosphamide conditioning regimen. The red cells from the same unit are retained for re-transfusion to the donor during the subsequent collection of bone marrow.

Donor and recipient are compatible at the major loci within the human histocompatibility complex. Ideally, there should be no blood group incompatibility, although reduction in red cell antibodies to inconsequential levels can be effected by means of large volume plasma exchange ${ }^{14}$.

Twenty-four hours after administration of the buffy layer, which theoretically triggers immunologically competent cells in the recipient into cycle and hence renders them maximally responsive to cytotoxics, cyclophosphamide condi- tioning is commenced. In patients with severe acute aplastic anaemia, $50 \mathrm{mg} / \mathrm{kg}$ is given by intravenous infusion over half an hour on four consecutive days. In leukaemic patients undergoing first remission bone marrow transplantation a slightly different regimen is used; 60 $\mathrm{mg} / \mathrm{kg}$ of cyclophosphamide is given for two days, following which the patient rests for 24 hours and then, on the day of transplantation. undergoes 1000 total body irradiation at a rate of $9 \mathrm{rads} /$ minute. The object of these conditioning regimens is to destroy all immunologically competent lymphatic tissue which may be capable of mounting a rejection response.

Under general anaesthesia, and with informed consent, marrow is collected from the donor by multiple punctures of the sternum and both iliac crests. Between 1 and $3 \mathrm{ml}$ of marrow-rich blood are aspirated from each puncture site and a final volume of approximately $10 \mathrm{ml} / \mathrm{kg}$ of recipient's body weight collected The aspirated material is anticoagulated in heparin-containing culture medium and converted to a monocellular suspension by passing it through a series of stainless steel screens. The graft is infused over half an hour to the recipient. Attention is given to any discomfort in the chest which may be associated with multiple small fat emboli. The arterial oxygen saturation is observed at the same time.

Apart from experiencing some discomfort donors are usually able to leave hospital the next day and have little trouble in attending the Cell Support Section to donate buffy layer on the separator.

The recipient is nursed in isolation and receives buffy layer daily for the first five days of the posttransplantation week. All support is then discontinued unless the patient is pyrexial or has significant thrombocytopenic bleeding. In the face of pyrexia, antibiotics (tobramycin. cephamandole, and metranidazole) are commenced while awaiting appropriate cultures. Failure to lyse fever within 24 hours is an indication for allogeneic white cells, with an arbitrary level of 1.5 granulocytes $\times 10^{10}$ the daily goal. 


\section{IN VITRO BONE MARROW CULTURE}

Culturing haematopoietic stem cells or committed progenitors in semisolid agar in the laboratory is a useful technique which may be applied to monitoring the adequacy of the graft being infused ${ }^{15}$. In principle, the marrow is cultured in a system that provides both the nutrients and the stimulating substances necessary for the growth and proliferation of the progenitor cells. The appearance of small cell aggregates can then be counted, thereby providing an index of the number of stem cells in the graft.

In practice, the stimulating substance is a glycoprotein which is elaborated and released into the agar. The marrow from the donor is washed and suspended in a second agar layer called the overlayer in a $35 \mathrm{~mm}$ petri dish which is then incubated in a humidified atmosphere containing a fixed amount of carbon dioxide at $37^{\circ} \mathrm{C}$. The appearance of clusters and colonies are determined at days $0,3,7,10$ and 12 . By definition, clusters contain between 3 and 49 cells, white colonies have more than 50 cells present.

Under normal circumstances the earliest evidence of in vitro marrow growth is evident between day 3 and 7 , but the optimal colony cluster ratio has been recorded in our laboratory at day 10 . In each of the patients discussed in the case studies normal numbers of colonies and clusters were demonstrable at this time, establishing that committed haematopoietic stem cells, at least for the monocyte macrophage line, were present in normal numbers. Experience has demonstrated that such in vitro growth patterns correlate with the supply of adequate numbers of stem cells as reflected in uniform engraftment of patients where sensitisation has not previously taken place.

\section{DISCUSSION}

Bone marrow transplantation has become increasingly successful, especially in the last decade. This improvement reflects both a better appreciation of the need to match donor and recipient at the major histocompatibility complex and a clearer understanding of the immunobiology of the procedure, particularly in providing a sufficient number of haematopoietic stem cells to bring about marrow reconstitution. Nevertheless, as these two important variables have been managed, new challenges have emerged.

It has become apparent that prior exposure to blood or blood group antigens may lead to isoimmunisation in the recipient and subsequent graft rejection. Accordingly, patients being considered for transplantation should be referred early to a transplantation centre so that this essentially iatrogenic complication may be avoided.

A second source of failure now amenable to treatment is that of thrombocytopenic haemorrhage. With the steady improvement of technique for allogeneic platelet transfusion, this complication has diminished in importance. Regrettably, this advance may be a twoedged sword in that platelet transfusions may be used indiscriminately in the short term in the hope that conservative therapy may allow spontaneous marrow recovery to occur, particularly in patients with severe acute aplastic anaemia. In this situation the problems of isoimmunisation are enormous. Platelet survival may be shortened and the option of transplantation may be lost by inadvertent stimulation of antibody production directed against donor cells.

With control of thrombocytopenic haemorrhage, infection, usually bacterial, has taken over as the major cause of morbidity and mortality in the transplant patient. Two major factors contribute to the propensity to infection. Firstly, in patients with severe acute aplastic anaemia, severe granulocytopenia is part of the disease and many of these patients reach the transplant centre with established infection, commonly of the respiratory tract. Secondly, the conditioning regimens aimed at diminishing host immune competence in order to facilitate graft acceptance superimpose immune destruction of the host upon pre-existent granulocytopenia.
Since engraftment should not be a problem in properly selected donors who have not been previously isoimmunised, it follows that carefully selected allogeneic platelet and granulocyte support occupies a crucial role in determining the success of any marrow transplantation.

The infusion of buffy layer to boost the number of stem cells given to the patient is theoretically sound. However, recent evidence suggests that this particular manoeuvre is less helpful than previously anticipated, particularly if adequate numbers of stem cells are collected in the initial graft.

Nevertheless, the provision of white cells and platelets during the first week following transplantation has notably improved the general condition of the patients. Until such time as a randomised prospective study becomes available, the advantages are sufficiently attractive for us to continue with this procedure.

Of a less controversial nature is the use of allogeneic granulocyte support in the patient who is pyrexial and pancytopenic following transplantation. Despite sugges tions that the fever may be related to neutropenia per se rather than infection $^{16}$, and the suggestion that prophylactic granulocyte transfusions are not helpful, our own experience has been otherwise. It remains to be determined by prospective randomised study whether the provision of adequate numbers of functionally intact granulocytes to the infected heut ope figh parkient following marrow transplantation can be safely omitted.

\section{CONCLUSION}

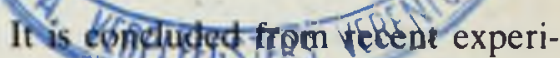
ence trat 20 hesusion of buffy layer containing granulocytes and platelets, both routinely in the week following transplantation and subsequently for the indications of fever and haemorrhage, is beneficial in the bone marrow transplant recipient. We emphasise the need to maintain rigid quality control in number and function of cells transfused, to recruit an adequate donor panel, and to maintain a highly trained nursing staff to operate an active Cell Support Section as an in- 
tegral part of a clinical bone marrow transplantation programme

\section{ACKNOWLEDGEMENTS}

Supported by the University of Cape Town Leukaemia Centre, The Medical Research Council and The National Cancer Association. Dr D Dubovsky helped with preparation of the manuscript, Jackie Davies did the typing and Sheila Katcher provided bibliographic assistance.

We thank physicians for referring the patients for transplantation, staff from the Cell Support Section for providing the components, and nursing colleagues from the Transplantation Unit for excellent care of the patients.
1. Storb, $\mathrm{R}$ et Al Marrow transplantation in thirty untrans fused patients with severe aplastic anemia. Annals of Internal Medicine 92: 30-36. 1980.

2. Griscelli. C et $A$ l Transplantation of lymphoid cells in patients with severe combined immunodeficiency (SCID). In: Thierfelder. S; Rodt. H. Kolb. H J ed. Immunobiology of Bone Marrow Transplantation Springer-Verlag New York. 1980 p.403-4019.

Storb, R for the Seattle Marrow Transplant Team Recent results in marrow transplantation for the treatment of aplastic anemia and acute leukemia in Seattle. In: Thierfelder, $\mathrm{S}$; Rodi, $\mathrm{H}$ : Kolh. $\mathrm{H}$ J ed. Immunob ology of Bone Marrow Transplantation. Springer Verlag New York 1980 p. 367-374.

4. Thomas. E D et Al Marrow transplantation for paticnts with acute lymphoblastic leukemia in remission. Blood 54: $46 \&-4761979$

5. Thomas, E D et Al Marrow transplantation for acute nonlymphoblastic leukemia in first remission. New England Journal of Medicine 301: 597-599 1979.

6. Wara, D W; Brunner, W C; Amman. A J Graft versus host disease: pathogenesis, recognition. prevention and treatment. Current Problems in Pediatrics 8: $1-49$ 1978.

Bennett. J M et Al Proposals for the classification of the acute leukacmias. French-A merican-British (FAB) co- operative group. British Journal of Haematology 33 $45 \mathrm{i}-4581976$

8. Mauer, A M Therapy of acute lymphoblastic leukemia in childhood Blood 56: 1-10 1980.

9. Jacobs. P: Jacobson, J. A practical method for ensuring long-term venous access. Journal of the Royal Sociery of Medicine 72: 263-265 1979.

10. Thomas. E D et Al Bone marrow Iransplantation. New" England Journal of Medicine 292: 832-843: 895-902 1975

11. Dubovsky, D; Kernoff. L; Jacobs, P. Rapid remission induction in adult acute non-lymphoblastic leukaemia. European Journal of Cancer 14: 1179-1183 1978.

12. Buckner, C D for the Seattle Bone Marrow Transplant Team. Allogeneic marrow transplantation for patients with acute leukemia. Transplantation Proceedings 11 215-218 1979

13. Morris. C D W et Al Epsilon aminocuproic acid (EACA) induced myopathy. In press.

4. Wood, $L$ ef $A$ / The role of continuous-flow blood fras tion separators in clinical practice. South African Med cal Journal 59: 99-104. 1981.

15. Jacobs. P el Al Bone martow culture in vitro. A technique for analysis and permanent recording of cellular composition. Experimental Hematology 7: 177-182 1979

16. Strauss. R G Therapeutic neutrophil transfusions. Are controlled studies no longer appropriate? Amencan Journal of Medicine 65: 1001_-1010 1978

\section{Voltooide Navorsing / Completed Research}

\section{DIE ROL EN TAAK VAN DIE SWART GE M E E S K A P G E S O N D - HEIDVERPLEEGSTER IN LEBOWA, VENDA EN GAZANKULU}

\section{WILHELMINA COMBRINCK GROBBELAAR D Litt et Phil Universiteit van Suid-Afrika}

Met hierdie navorsingstudie is in die lig van die wêreldbeskouing gesondheid vir almal teen die jaar 2000 gepoog om die rol en taak van die Swart gemeenskapverpleegster in Lebowa, Venda en Gazankulu te bepaal.

Die navorsing het aan die lig gebring dat die verpleegster in die betrokke state die sleutelrol speel in die lewering van "n omvattende primêre gesondheidsorgdiens aan 'n groot deel van die bevolking. Haar rol en taak is teen die agtergrond van die agrogeografiese-, ekonomiese- en demografiese faktore van die onderskeie lande beskou. Omdat al drie lande beskou word as ontwikkelende lande, speel dié faktore 'n deurslaggewende rol in die gesondheidstatus en -dienste.

Die invloed van die sendelinge, die beleid van die Republiek van Suid-Afrika en die siening van die WGO met betrekking tot gesondheid op die dienste van die state is bespreek. Die organisasie - beheer, finansiering, aard en omvang van bestaande gesondheidsdienste is kortliks uiteengesit.

'n Ontleding van die gesondheidsmannekrag het die problematiek van die ernstige tekort aangedui en is die rol en taak van die gemeenskapsverpleegster teen hierdie agtergrond bespreek

Die persoonlike eienskappe van die gemeenskapverpleegster is ontleed en het interessante feite aan die lig gebring.

Statistiese ontleding van gerekenariseerde gegewens van die instrument het die huidige omvattende rol en taak van die gemeenskapsverpleegster gereflekteer Hieruit blyk dat sy veral betrokke is in gesondheidsvoorligting, primêre kliniese funksies ten opsigte van moeder- en kindersorg, insluitende kraamdienste en gesinsbeplanning, sorg van die skoolkind, volwassene en bejaarde, terwyl sy in 'n minder mate betrokke is by bevoegdhede soos onderrig van student- en leerlingverpleegkundiges en administratiewe aangeleenthede.

Die werklike en potensiële rol en taak van die gemeenskapsverpleegster is ontleed en bepaal met inagneming van faktore wat gemeenskaps- en gesondheidsprobleme beïnvloed. Op grond hiervan is aanbevelings met betrekking tot die benutting, opleiding en voorbereiding van die verskillende kategorieë gemeenskapsverpleegsters gemaak sodat sy 'n professioneel wetenskaplik gefundeerde gemeenskapsdiens kan lewer maar ook om die bevolking op te voed tot selfsorg en aanvaarding van verantwoordelikheid vir hul eie gesondheid.

Alleen op dié wyse kan die gemeenskapsverpleegsters van Lebowa, Venda en Gazankulu hoop om die strategie gesondheid vir almal teen die jaar 2000) te verwesenlik. 


\section{NURSING PERSONNEL ADMINISTRATION WITHIN A HOSPITAL}

\section{ROSALIE A.E. THOMPSON \\ Degree of Master in Public Administration University of Cape Town}

Personnel administration is a relatively new discipline within the international health service industry. The need for professional personnel administration within the health services of South Africa has not yet been fully recognised. This is evidenced in the dearth of literature and the absence of training courses and posts within the hospital services.

In this thesis, an overview of nursing personnel administration is presented rather than an in-depth study of any single aspect. The discussion is related to the present and future needs of the profession as they are perceived, specifically in relation to hospital practice. The emphases which emerge do not necessarily coincide with those which are presently receiving priority in the field of personnel administration in general, although some of these trends have been mentioned.

The thesis is in two parts. Part One is an overview of Nursing Administration in South Africa, and shows that although the nurse qualified in administration occupies a position with immense scope and potential in the profession and in society, this has not been evidenced in the training and development programs for nursing administrators. The history of nurse administrator training and related legislation is traced and comprehensive discussion of contemporary education in nursing administration in South Africa is included. Proposals for more appropriate courses, in line with international trends, are made. Statistics are quoted in support of statements wherever possible. The national manpower situation in relation to nurse administrators is given and is cause for concern. These figures would seem to confirm the fact that the crucial role of good management as a precondition of good care has yet to be fully recognised. The writer highlights the need for in-depth study of the role of the nurse administrator.

The second part forms the major portion of the thesis and is divided into eight chapters. The opening chapter makes a case for hospital personnel administration and describes how this may be implemented. The role of the nurse personnel administrator is introduced and this is expanded in each of the chapters which follow. Considerable attention is given to wastage and absenteeism amongst nurses, and staff recruitment and selection. This is done within the context of nurse manpower planning. The discussion includes an extensive survey of the literature and an analysis of the situation in South Africa. Statistical data support the discussion throughout.
The establishment of a central registration and admission centre is proposed. Such a centre would supply information on nusing and nurse education; clarify admission criteria, administer psychological, medical and other examinations where required. In addition complete records of both applicants and admissions would be available. Studies of applicants to nurse training programs are urgently required because of their relevance to recruitment.

The need for standardised methods for classifying and measuring withdrawal amongst nurses for use by the profession and employers is highlighted. Until such measures are available and in use nationally, and indeed internationally, comparative analyses are not possible.

Although generalisations cannot be made from the studies which are reviewed, the aspect which emerges as being of greatest significance in wastage is the organisational environment which includes the associated administrative procedures.

The chapter on recruitment and selection reviews trends over the past two decades in relation to student and pupil nurse training and reveals considerable racial variations within the different courses. The effect of the introduction of a standard 10 or equivalent certificate for entrance to student nurse training is examined. Recruitment to the profession would appear to be inadequate and the need for scientific measures for assessing manpower requirements are evident. The advisability of recruiting mature students and the training programs which would be required are mentioned briefly. Limited attention is given to selection procedures because the focus has been shifted from such procedures (or the lack of them) as the prime reason for attrition and quality of performance, to a more balanced perspective which includes all aspects of the ecology of the learning process.

A short chapter on job analysis is followed by a chapter on staff development and education in which attention is focussed on orientation, leadership and organisation development. The need to take cognisance of the social influences in the work environment when designing programs is emphasised. Functional and dysfunctional consequences of leadership training are mentioned and the future trends affecting staff development and education are summarised.

Performance appraisal is reviewed in chapter seven and the developmental purposes of appraisal are emphasised.

In the conclusion the writer specifies areas requiring further research, and states that the nursing profession must deliberately enter the field of personnel administration if the nurse is to maintain quality in nursing care, since this is directly related to the quality of nursing administration. 